Available online at

SciVerse ScienceDirect

www.sciencedirect.com
Elsevier Masson France

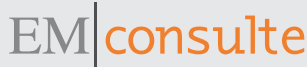

www.em-consulte.com

\title{
Isolation of keratinophilic fungi from soil in Isfahan province, Iran
}

\section{Isolement de champignons kératinophiles du sol dans la province d'Isfahan, Iran}

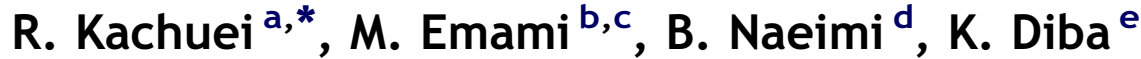

\begin{abstract}
${ }^{a}$ Molecular Biology Research Center, Baqiyatallah University of Medical Sciences, Tehran, Iran
${ }^{\mathrm{b}}$ Department of Medical Parasitology and Mycology, Faculty of Public Health, Tehran University of Medial Sciences, Tehran, Iran

${ }^{\mathrm{C}}$ Department of Microbiology, School of Basic Science, Islamic Azad University- North Tehran branch, Tehran, Iran

${ }^{\mathrm{d}}$ The Persian Gulf Marine Biotechnology Research Center, Bushehr University of Medical Sciences, Moallem Street, PO Box 3631, Bushehr, Iran

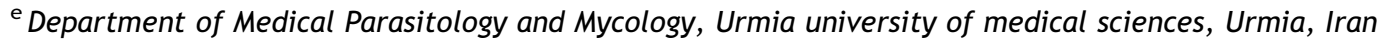

Received 18 June 2011; received in revised form 30 October 2011; accepted 1 November 2011

Available online 29 December 2011

\section{KEYWORDS}

Keratinophilic fungi;

Isolation;

Soil;

Iran

\begin{abstract}
Summary
Objective. - To evaluate the epidemiology of keratophilic fungi in Isfahan province, Iran. Material and methods. - The present research has been conducted on soil samples collected from 16 townships of Isfahan province. For isolate geophilic dermatophytes and keratinophilic fungi, the keratin baiting technique has been applied.

Results. - Of 800 soil samples examined, 588 (73.5\%) keratinophilic fungi were isolated. The present studied recognized 727 isolates including 16 species of 11 genus, as follows: Chrysosporium keratinophilum (31.4\%), C. pannicola (16.9\%), C. tropicum (15.4\%), Microsporum gypseum (12.4\%), Chrysosporium spp. (9.9\%), C. indicum (7\%), Sepedonium spp. (3.3\%), Malbranchia spp. (1\%), Trichophyton terrestre $(0.8 \%)$, T. ajelloi and Paecilomyces lilacinus (0.4\%), Engyodontium album and Acremonium spp. (0.3\%), Curvularia spp., Fusarium spp. and Ulocladium spp. $(0.1 \%)$. In this study, E. album was isolated for the first time in this country (Iran). The frequency these keratinophilic fungi are discussed in relation to different agents such as soil $\mathrm{pH}$.

Conclusion. - This study contributes to the knowledge of keratophilic fungi in Iran.

(C) 2011 Elsevier Masson SAS. All rights reserved.
\end{abstract}

\footnotetext{
* Corresponding author.

E-mail address: kachueir@gmail.com (R. Kachuei).
} 


\section{MOTS CLÉS}

Champignons

kératinophiles ;

Isolement ;

Sol ;

Iran

\section{Résumé}

Objectif. - Évaluer l'épidémiologie des champignons kératinophiles dans la province d'Isfahan, Iran.

Matériel et méthodes. - La présente recherche a été menée sur des échantillons de sol prélevés dans 16 cantons de la province d'Isfahan. Pour isoler les dermatophytes et les champignons géophiles et kératinophiles, la technique d'appâtage à la kératine a été appliquée.

Résultats. - Un total de 800 échantillons de sol a été examiné parmi lesquels 588 (73,5\%) avaient des champignons kératinophiles. La présente étude a permis d'isoler 727 champignons appartenant à 16 espèces de 11 genres différents comme suit : Chrysosporium keratinophilum (31,4 \%), C. pannicola (16,9 \%), C. tropicum (15,4 \%), Microsporum gypseum $(12,4 \%)$, Chrysosporium sp. (9,9\%), C. indicum (7\%), Sepedonium sp. (3,3\%), Malbranchia sp. (1\%), Trichophyton terrestre $(0,8 \%)$, T. ajelloi et Paecilomyces lilacinus $(0,4 \%)$, Engyodontium album et Acremonium sp. (0,3\%), Curvularia sp., Fusarium sp. et Ulocladium sp. $(0,1 \%)$. Dans cette étude $E$. album a été isolé pour la première fois dans ce pays (Iran). La fréquence de ces champignons kératinophiles est discutée en relation avec différents agents tels que le $\mathrm{pH}$ du sol.

Conclusion. - Cette étude contribue à une meilleure connaissance de l'épidémiologie des champignons kératinophiles en Iran.

(C) 2011 Elsevier Masson SAS. Tous droits réservés.

\section{Introduction}

Keratinophilic fungi are a group of fungi that colonize various keratinous substrates and degrade them to components of low molecular weight. These include a host of filamentous fungi representing mainly hyalohyphomycetes and several other taxonomic groups [13].

Many keratinophilic fungi frequently live as a parasite on keratinous tissue as skin, nails and hair in man and animals; some of them share certain morphological features, constituting a special group called dermatophytes. Most species of dermatophytes are anthropohilic or zoophilic in their natural habitat, while some occur in soil as saprophytes and are termed geophilic dermatophytes $[13,19,27]$.

Many surveys have been carried out in different parts of the world to study the distribution of these fungi in soil $[1,7-$ $9,11,22-24,26,33,34]$. During recent years there are reports on the isolation of dermatophytes and related keratinophilic fungi from Iran soils [14,20]. However, our knowledge from keratinophilic fungi in Iran is still fragmentary. The province of Isfahan, with a land area of approximately $107,027 \mathrm{~km}^{2}$, is located in the centre of the Iranian plateau. Constituting of 17 townships, this province had a population of 4,559,256 according to the 2006 census. The province experiences a moderate and dry climate on the whole, ranging between $40.6{ }^{\circ} \mathrm{C}$ and $10.6{ }^{\circ} \mathrm{C}$ on a cold day in the winter season. From 17 townships, the keratinophilic fungal flora of the Isfahan city only has been partially investigated [30]. But due to climate and vegetation diversity in Isfahan province, the present study carried out with the goals as follow:

- survey of frequency of keratinophilic fungi in studied regions;

- $\mathrm{pH}$ measurement from soil of the studied regions and associated with keratinophilic fungi;

- effect of climate types in the frequency of this group of fungi.

\section{Material and methods}

A total of 800 soil samples were collected from 800 different locations in 16 townships (including 16 cities and 16 villages) in Isfahan province. Fifty soil samples from each township (including 30 samples from central city and 20 samples from selected village) were collected (Table 1).

Sampling carried out in winter and work on the samples lasted for 18 months (2006-2008). Sampling locations in cities include squares, boulevard, street side, area offices, coastal and forest parks, riverine, waterfall along... and villages samples include corral livestock and domestic animals, nests, farm land, fruit gardens, garden houses... Soil samples to the amount of 200-300 g for each sample were collected from superficial layer with depth not exceeding $2-$ $5 \mathrm{~cm}$. The samples were placed in sterile polyethylene bags, transported immediately to the laboratory and were store at low temperature $\left(4^{\circ} \mathrm{C}\right)$ until tested. $\mathrm{pH}$ of the samples was measured immediately in a 1:5 soil/deionised water suspension (w/v) using a $\mathrm{pH}$ meter according to A1-Musallam [2].

Townships of studied base on air temperature and humidity that in the sampling time was measured, also with considering the geographical situation were divided to three groups including townships with cold and semi-wet climate, seminomadic climate, desert and brackish climate (Table 2 ).

Hair baiting technique was followed to isolate dermatophytes and related keratinophilic fungi from the soil samples. Seventy grams of soil from each sample were placed in $9 \mathrm{~cm}$ diameter sterilized petri dishes and baited with a mixture of sterile human child girls' hairs and horse to rate of $1 \mathrm{~g}$ for one petri dish.

Sterilization of hairs was performed with cut into pieces $1-2 \mathrm{~cm}$, then were placed in $9 \mathrm{~cm}$ diameter glass petri dishes and covered with aluminium foil, then was autoclave.

The plates were then moistened with sterile distilled water and incubated at room temperature $\left(25^{\circ} \mathrm{C}\right)$ for a period of six weeks and were remoistened with sterile distilled water whenever necessary. The plates were observed periodically for the isolation and identification of keratinophilic 
Table 1 Frequency of keratinophilic fungi isolated from soils of 16 townships in the province of Isfahan, Iran.

Fréquence des champignons kératinophiles isolés du sol dans 16 cantons de la province d'Isfahan, Iran.

\begin{tabular}{|c|c|c|c|c|c|c|c|c|c|c|c|c|c|c|c|c|c|c|}
\hline & \multicolumn{16}{|c|}{ Townships } & \multirow[t]{2}{*}{ Total } & \multirow[t]{2}{*}{$\%$ frequency } \\
\hline & Ard & Bor & Fer & Fla & Fsh & Gol & Kas & Kha & Kho & Len & Mob & $\mathrm{Nai}$ & $\mathrm{Naj}$ & Nat & Sem & Sha & & \\
\hline No.of samples ex. & 50 & 50 & 50 & 50 & 50 & 50 & 50 & 50 & 50 & 50 & 50 & 50 & 50 & 50 & 50 & 50 & 800 & \\
\hline No.of positive & 15 & 17 & 42 & 42 & 40 & 40 & 32 & 45 & 42 & 41 & 45 & 47 & 34 & 34 & 41 & 31 & 588 & \\
\hline Percentage of positive & 30 & 34 & 84 & 84 & 80 & 80 & 64 & 90 & 84 & 82 & 90 & 94 & 68 & 68 & 82 & 62 & 73.5 & \\
\hline \multicolumn{19}{|l|}{ Species isolated } \\
\hline Acremonium spp. & 0 & 0 & 0 & 0 & 1 & 0 & 0 & 0 & 0 & 0 & 0 & 0 & 0 & 0 & 0 & 1 & 2 & 0.27 \\
\hline Chrysosporium indicum & 1 & 0 & 4 & 2 & 6 & 3 & 5 & 4 & 9 & 3 & 2 & 3 & 6 & 3 & 0 & 0 & 51 & 7 \\
\hline C. keratinophilum & 5 & 5 & 19 & 13 & 14 & 17 & 14 & 22 & 15 & 9 & 16 & 20 & 12 & 21 & 14 & 13 & 229 & 31.45 \\
\hline C. tropicum & 3 & 4 & 7 & 4 & 11 & 8 & 6 & 9 & 7 & 7 & 8 & 9 & 10 & 4 & 8 & 7 & 112 & 15.38 \\
\hline C. pannicola & 4 & 2 & 8 & 7 & 9 & 12 & 14 & 10 & 11 & 7 & 7 & 9 & 4 & 6 & 5 & 8 & 123 & 16.89 \\
\hline Chrysosporium spp. & 0 & 1 & 5 & 10 & 5 & 0 & 3 & 13 & 5 & 0 & 8 & 7 & 0 & 2 & 9 & 4 & 72 & 9.89 \\
\hline Curvularia sp. & 0 & 0 & 0 & 0 & 0 & 0 & 0 & 0 & 0 & 0 & 0 & 0 & 0 & 0 & 0 & 1 & 1 & 0.13 \\
\hline Engiodontium album & 2 & 0 & 0 & 0 & 0 & 0 & 0 & 0 & 0 & 0 & 0 & 0 & 0 & 0 & 0 & 0 & 2 & 0.27 \\
\hline Fusarium spp. & & & & & & & & & & & & 1 & & & & & 1 & 0.13 \\
\hline Malbranchia spp. & & & 1 & & & & & & 3 & & & & & & 2 & 1 & 7 & 0.96 \\
\hline M. gypseum & 0 & 8 & 8 & 8 & 5 & 4 & 1 & 6 & 3 & 16 & 6 & 5 & 4 & 1 & 13 & 2 & 90 & 12.36 \\
\hline Paecilomyces lilacinus & 1 & & & & & & & 2 & & & & & & & & & 3 & 0.41 \\
\hline Sepedonium spp. & 3 & 2 & & & & & 4 & 4 & & 6 & & & 2 & 3 & & & 24 & 3.3 \\
\hline Trichophyton ajelloi & & & 2 & 1 & & & & & & & & & & & & 3 & 0.41 & \\
\hline T. terrestre & 1 & & 1 & & 1 & 2 & & & & 1 & & & & & & & 6 & 0.82 \\
\hline Ulocladium spp. & & & & & & & & & & & 1 & & & & & & 1 & 0.13 \\
\hline Unknown & 1 & & & & & & & & & & & & & & & & 1 & 0.13 \\
\hline Total & 21 & 22 & 53 & 46 & 52 & 46 & 47 & 70 & 53 & 49 & 49 & 54 & 38 & 40 & 51 & 37 & 728 & 100 \\
\hline
\end{tabular}


Table 2 Separation of studied townships according to the type of climate.

Répartition des cantons étudiées selon le climat.

\begin{tabular}{ll}
\hline Climate & Townships \\
\hline Cold and semi wet & $\begin{array}{l}\text { Khansar, Semirom, Feraidan, } \\
\text { Feraidoonshahr, Golpayegan, Natanz }\end{array}$ \\
Semi nomadic & $\begin{array}{l}\text { Borkharomeimeh, Shahreza, } \\
\text { Flavarjan, Lenjan, Mobarekeh }\end{array}$ \\
Desert & $\begin{array}{l}\text { Ardestan, Khomainishahr, Kashan, } \\
\text { Naiin, Najafabad }\end{array}$ \\
\hline
\end{tabular}

fungi. Isolation were carried out by direct transfer of mycelium from the baits to sabouraud dextrose agar medium with cyclohexamide $(1 \mathrm{mg} / \mathrm{mL})$ and chloramphenicol $(0.1 \mathrm{mg} / \mathrm{mL})$, then incubated at room temperature for a period of two weeks. Identification of keratinophilic fungi was carried out according to standard procedures $[15,27]$. In this study, to confirm the existence of Malbranchia spp. and absence of its similar fungus (Coccidioides immitis), the fungus inoculated intraperitoneally to male mice.

\section{Result}

Among the 800 soil samples, 588 (73.5\%) samples were positive for keratinophilic fungi (Table 1). In the present study, 727 isolates of keratinophilic fungi and one isolate of unknown aerial actinomycete were isolated. Keratinophilic fungi were belonging to 16 species of 11 genus as follows: Chrysosporium keratinophilum (31.4\%), C. pannicola (16.9\%), C. tropicum (15.4\%), Microsporum gypseum (12.4\%), Chrysosporium spp. (9.9\%), C. indicum (7\%), Sepedonium spp. (3.3\%), Malbranchia spp. (1\%), Trichophyton terrestre $(0.8 \%)$, T. ajelloi and Paecilomyces lilacinus (0.4\%), Engyodontium album and Acremonium spp. (0.3\%), Curvularia spp., Fusarium spp. and Ulocladium spp. (0.1\%) (Table 1$)$.

In this study, keratinophilic fungi were isolated more in urban areas than in rural areas (Fig. 1).

The most keratinophilic fungi species was detected from region with cold and semi-wet climate (38.5\%). The most

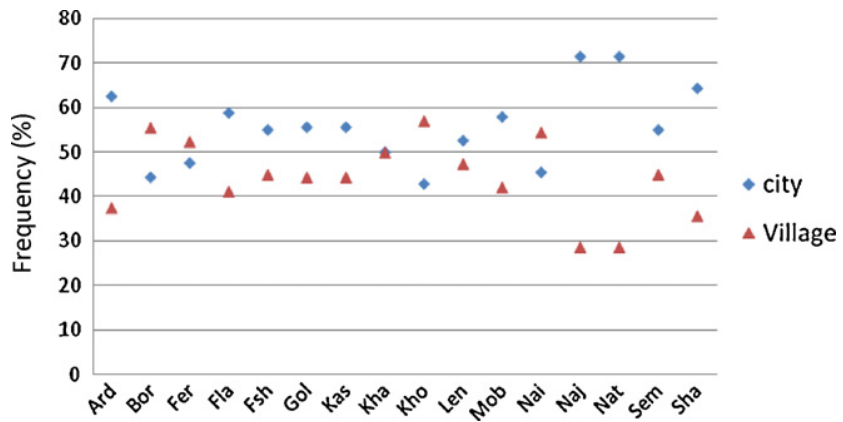

Figure 1 Frequency of keratinophilic fungi isolated from soils of urban and rural regions from 16 townships in the province of Isfahan, Iran.

Fréquence des champignons kératinophiles isolés du sol dans les zones urbaines et rurales de 16 cantons de la province d'Isfahan, Iran.

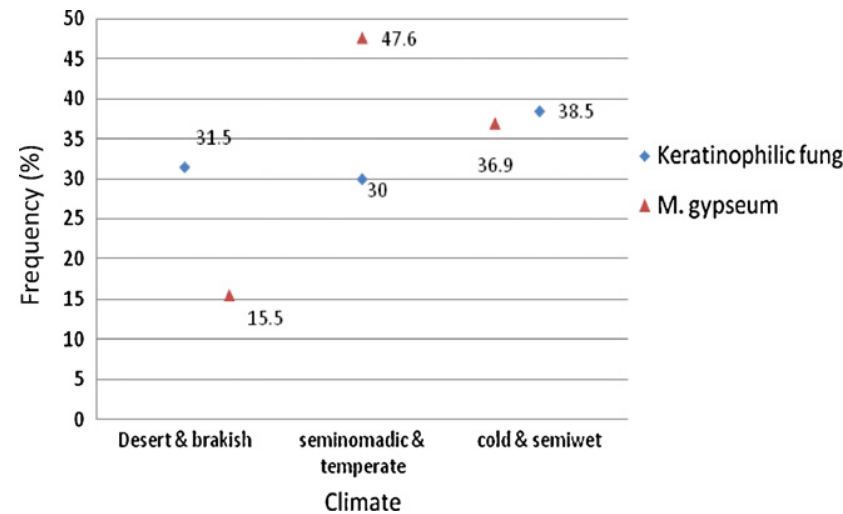

Figure 2 Frequency of keratinophilic fungi and M. gypseum isolated from soils of 16 townships in the province of Isfahan (Iran) at different climates.

Fréquence des champignons kératinophiles et de $M$. gypseum isolés du sol de 16 cantons de la province d'Isfahan, (Iran) à différents climats.

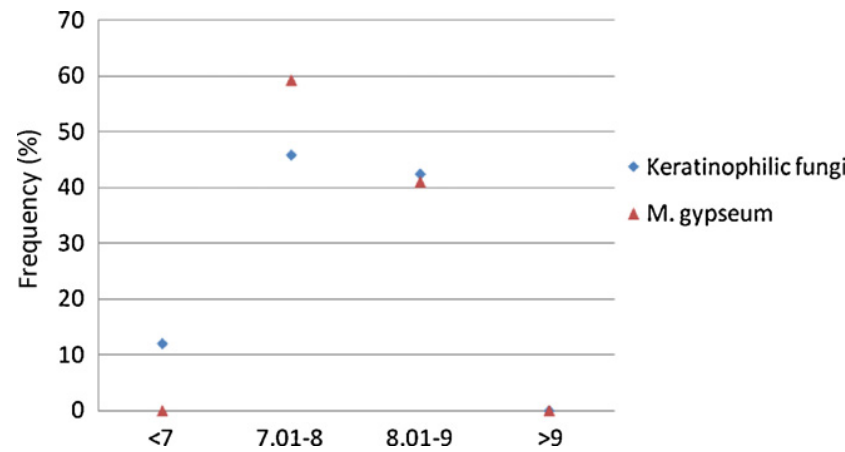

Figure 3 Frequency of keratinophilic fungi and $M$. gypseum isolated from soils of 16 townships in the province of Isfahan (Iran) at pH different values.

Fréquence des champignons kératinophiles et de $M$. gypseum isolés du sol de 16 cantons de la province d'Isfahan (Iran) à différents $\mathrm{pH}$.

M. gypseum species was detected from region with seminomadic and temperate climate (47.6\%) (Fig. 2 ). Fig. 3 shows the distribution of the keratinophilic fungi in relation to soil $\mathrm{pH}$. We found $45.7 \%$ keratinophilic fungi from the soil samples with $\mathrm{pH}: 7.01-8,42.3 \%$ from $\mathrm{pH}$ : $7.01-8$ and $12 \%$ from $\mathrm{pH}: 6-7$. In the present study, the most $M$. gypseum species(59.1\%) were isolated from the soil samples with $\mathrm{pH}$ : 7.01-8.

\section{Discussion}

This study showed that the soil of studied areas was rich of keratinophilic fungi and geophilic dermatophytes, because these fungi were isolated from more than $70 \%$ of the total soil sample studied. Chrysosporium spp. (80.6\%) were the most prevalent species of fungal isolates. They were isolated from more studied samples. Several studies show that Chrysosporium spp. frequently isolated from soil samples and a wide spread have in the soil $[1,9,11,23,32]$. 
In this study, M. gypseum, Trichophyton ajelloi and Trichophyton terrestre were isolated. Several researchers also inside of Iran, cases of this kind of dermatophytes have reported $[1,2,14,20,23,26,30]$.

Cases of human infections caused by $M$. gypseum and $T$. ajelloi were reported, also $T$. terrestre as agent of dermatophytosis in humans and animals is known $[3,16,18,21,25,28,29]$.

In the present study, Engyodontium album has been isolated for the first time from Iran soil. E. album is regarded as a keratinophilic fungus $[15,17]$. E. album as human infections such as keratitis, brain abscess, endocarditis and eczema vesiculosum have been reported [5].

In general, the soil of Isfahan province to several reasons were rich of keratinophilic fungi:

- sampling was performed from the soil surface and maximum depth of $3 \mathrm{~cm}$ that was according to Tuck soon [31];

- bait or substrate used in this study was mixture of the horse hair (due to high volume keratin) and the immature girl (due to being dry hair), according to the other researchers [1];

- the third factor is soil pH. The first time Bohme and Ziegler [6], effect of the $\mathrm{pH}$ on the soil keratinophilic fungi were studied, they reported that keratinophilic fungi are not seen in soils with low pH (3 to 4.5). Garg [12], also acidic soils with $\mathrm{pH}=5.9$ were introduced free of the keratinophilic fungi. Asahi et al. [4], as well as concluded that keratinolytic enzymes in $\mathrm{pH}=6-9$ and especially, the extracellular keratinase were active in $\mathrm{pH}=9$. Nasr-Esfahani [10] the best $M$. gypseum growth medium, soils of with $\mathrm{pH}$ weak alkaline was introduced. In this study, all 727 identified species of keratinophilic fungi were isolated from soil with the $\mathrm{pH}=6-9$. We found $45.7 \%$ keratinophilic fungi from the soil samples with $\mathrm{pH}$ : 7.01-8, $42.3 \%$ from $\mathrm{pH}: 7.01-8$ and $12 \%$ from $\mathrm{pH}$ : $6-7$. This confirmed the findings of others;

- according to findings of Garg [12] and Filipello Marchisio et al. [11], the most important factor in frequency of keratinophilic fungi is the existence of substrate and source of keratin in soil due to the activity of humans. The present study also confirmed this case. Because as you see in Fig. 1, in urban areas due to high population of humans and their activities, substrate and source of the keratin required for keratinophilic fungi is higher than the rural areas and therefore in this area the number of keratinophilic fungi were separated, more than the rural areas;

- according to research conducted by Garg [12] and Tuck Soon [31], soils rich in organic material, conditions for the spread of fungi in the soil are provided. In this study also, the most and the lowest keratinophilic fungi were isolated from Khansar township: 70 species $(9.6 \%)$ due to increase of soil organic matter and humus and Ardestan township: 21 species $(2.9 \%)$ due to decrease of soil organic matter, respectively;

- sixth factor is kind of the weather. In this study, the most species of keratinophilic fungi were isolated from soil samples of townships with cold and semi-wet climates. They were also isolated from more than $80 \%$ of the samples of these regions. However, soil samples of the townships with other climates had a high percentage of frequency. For example, they were isolated from more than $70 \%$ of the samples of the townships with seminomadic climate and almost $68 \%$ of samples of with desert climates. In addition, most strains of $M$. gypseum and all of $T$. ajelloii species were isolated from townships with semi-nomadic climate. Thus, we can conclude that kind of weather is effective on frequency of keratinophilic fungi.

Previous studies in Iran were limited to the quantity and quality of this group of fungi in the soil, but the present study showed the influence of some ecological factors on keratinophilic fungi in the soil.

\section{Disclosure of interest}

The authors have not supplied their declaration of conflict of interest.

\section{Acknowledgements}

We are grateful to Mr Geramishoar, Dr. M. R. Shidfar, Prof. F. Zaini, Prof. P. Kordbacheh, Dr. J. Hashemi, Dr. H. Mirhendi and personnel of Faculty of Public Health, Tehran University of Medial Sciences, Iran for helping us in research.

\section{References}

[1] Abdullah SK, Hassan DA. Isolation of dermatophytes and other keratinophilic fungi from surface sediments of the Shattal - arab river and it's creeks at Barsah, Iraq. Mycoses 1995;38:163-6.

[2] Al-Musallam A. A distribution of keratinophilic for sponsoring the color photography. fungi in animals folds in Kuwait. Mycopathologia 1990;112:65-70.

[3] Alvarez DP, de Bracalenti BJ. Dermatophytosis caused by Trichophyton ajelloi. Mycopathologia 1982;15:27-9.

[4] Asahi MI, Linquist RL, Mckerrow JH. Purfication and characterization of major extracellular proteinases from Trichophyton rubrum. Biochem J 1985;232:139-44.

[5] Augustinsky G, Kammeyer P. Engyodontium albom endocarditis. J Clin Micribiol 1990;1479-1481.

[6] Bohme H, Ziegler $\mathrm{H}$. Verbreitung and keratinophilic vonanixiopsis stercoraria (Hansen). Arch Clin Exp Dermatol 1965;223:422-8.

[7] Deshmukh SK, Mandeel QA, Verekar SA. Keratinophilic fungi from selected soils of Bahrain. Mycopathologia 2008;165:143-7.

[8] Deshmukh SK. Keratinophilic fungi isolated from soils of Mumbai, India. Mycopathologia 1999;146:115-6.

[9] Deshmukh SK, Verekar SA. Incidence of keratinophilic fungi from the soils of Vedanthangal Water Bird Sanctuary (India). Mycoses 2010.

[10] Esfahani Nasr B, Moghaddami M. The effect of some ecological factors on the survival of some dermatophytes. Iran J Public Health 1991;20:69-78.

[11] Filipello Marchisio V, Curetti D, Cassinelli C, Bordese C. Keratinolytic and karatinophilic fungi in the soil of Papua, New Guinea. Mycopathologia 1991;115:113-9.

[12] Garg APG. Ecology of keratinophilic fungi. Proc Indian Acode Sci (Plant Sci) 1985;94:149-63.

[13] Gugnani HC. Nondermatophytic filamentous keratinophilic fungi and their role in human infection. Rev Iberoam Micol 2000;17:109-14.

[14] Hedayati MT, Mirzakhani M. Survey of keratinophilic fungi in sewage sludge from wastewater treatment plants of Mazandaran. Islamic Republic of Iran. East Mediter Health J 2009;15:451-4. 
[15] Hoog GS, de, Guarro J, Gené J, Figueras MA. Atlas of Clinical Fungi, . 2nd ed., Utrecht: Universitat Rovira i Virgili, Reus: Centraalbureau voor Schimmelcultures; 2000.

[16] Ilkit M. Favus of the scalp: an overview and update. Mycopathologia 2010;170:143-54.

[17] Imonovièová A, Gódyová M, Kunert J. Engyodontium album, a new species of microscopic fungi for Slovakia and its keratinolytic activity. Biologia Bratislava 2004;59:17-8.

[18] Iwasawa M, Yorifuji K, Sano A, Takahashi Y, Nishimura K. Case of kerion celsi caused by Microsporum gypseum (Arthroderma gypseum) in a child. Nippon Ishinkin Gakkai Zasshi 2009;50: 155-60.

[19] Kwon-Chung KJ, Bennet JE. Medical Mycology. Philadelphia: Lea \& Febiger; 1992. p. 105-161.

[20] Moallaei H, Zaini F, Pihet M, Mahmoudi M, Hashemi J. Isolation of Keratinophilic Fungi from Soil Samples of Forests and Farm Yards. Iranian J Public Health 2006;35:62-9.

[21] Offidani A, Simoncini C, Scalise G. Tinea capitis due to Microsporum gypseum in an adult. Mycoses 1998;41:236-41.

[22] Palsson G. Geophilic dermatophytes in soil in Sweden. Studies on their occurrence and pathogenic properties. Acta Veterin Scand Supp 1968;25:5-89.

[23] Papini R, Mancianti F, Grassoti G, Cardini G. Survey of keratinophilic fungi: isolated from city park soils of Pise, Italy. Mycopathologia 1998;143:17-23.

[24] Periasamy A, Hilda A, Gopinath SCB. Keratinophilic fungi of poultry farm and feather dumping soil in Tamil Nadu, India. Mycopathologia 2004;158:303-9.
[25] Radoslaw S, Wieslawa S. zoophilic and geophilic dermatophytosis among farmers. Ann Agric Environ Med 2000;7: 125-9.

[26] Ramesh VM, Hilda A. Incidence of keratinophilic fungi in the soil of primary schools and public parks of.... Mycopathologia 1999;143:139-45.

[27] Rippon JW. Medical mycology: the pathogenic fungi and the pathogenic actinomycetes. Philadelphia: WB Saunders; 1988. p. $110-135$.

[28] Romano C, Asta F, Massai L. Tinea incognito due to Microsporum gypseum in three children. Pediatr Dermatol 2000; $17: 41$.

[29] Romano C. Onychomycosis due to Microsporum gypseum. Mycoses 1998;41:349-51.

[30] Shadzi S, Chadeganipour M, Alimoradi M. Isolation of keratinophilic fungi from elementary schools and public parks in Isfahan, Iran. Mycoses 2002;45:496-9.

[31] Tuck soon sh. isolation of kerationophilic fungi from soil in Malysia. Mycopathologia 1991;113:155-8.

[32] Ulfig k, Terakowski M, Lukasik W. A preliminary study on the occurrence of keratinolytic fungi .... Rocz Panstw Zakl Hig 1996;47:143-9.

[33] Vidyasagar GM, Hosmani N, Shivkumar D. Keratinophilic fungi isolated from hospital dust and soil of public places at Gulbarga, India. Mycopathologia 2005;159:13-21.

[34] Volz PA, Wlosinski MJ, Wasser SP. Sparse diversity of potential pathogenic soil micro-fungi in the Ukraine. Microbios 1991; 65:187-93. 